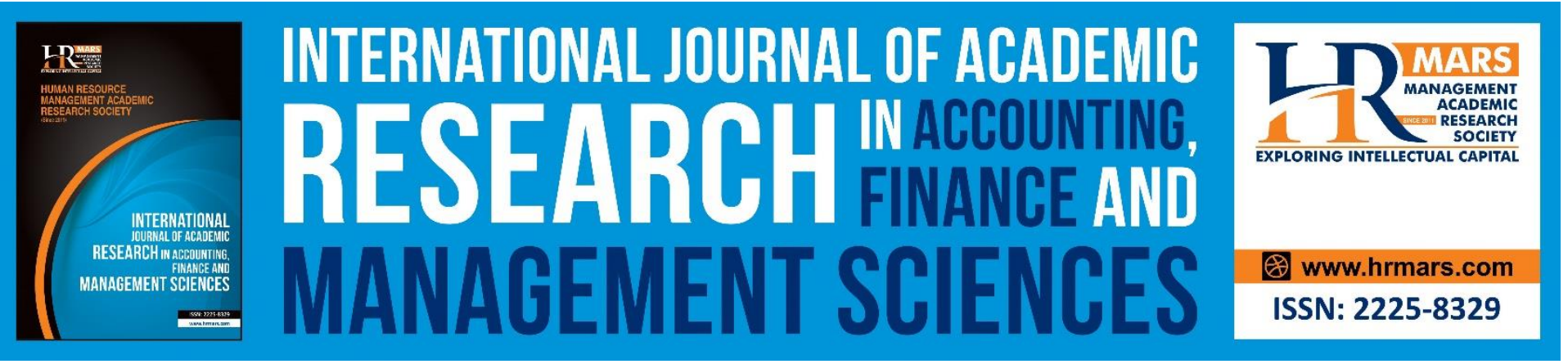

\title{
The Covid-19 Dashboard Sector Specific Impact: Malaysia Financial, Consumer Products and Health Care Services
}

Nur'Asyiqin Ramdhan, Noorita Mohammad, Nur Liyana Mohamed Yousop, Zuraidah Ahmad, Zuraidah Sipon and Norhasniza Mohd Hasan Abdullah

To Link this Article: http://dx.doi.org/10.6007/IJARAFMS/v11-i1/9244

DOI:10.6007/IJARAFMS /v11-i1/9244

Received: 05 January 2021, Revised: 31 January 2021, Accepted: 20 February 2021

Published Online: 18 March 2021

In-Text Citation: (Ramdhan et al., 2021)

To Cite this Article: Ramdhan, N., Mohammad, N., Yousop, N. L. M., Ahmad, Z., Sipon, Z., \& Abdullah, N. M. H. (2021). The Covid-19 Dashboard Sector Specific Impact: Malaysia Financial, Consumer Products and Health Care Services. International Journal of Academic Research in Accounting Finance and Management Sciences, $11(1), 327-337$.

\section{Copyright: (c) 2021 The Author(s)}

Published by Human Resource Management Academic Research Society (www.hrmars.com)

This article is published under the Creative Commons Attribution (CC BY 4.0) license. Anyone may reproduce, distribute, translate and create derivative works of this article (for both commercial and non-commercial purposes), subject to full attribution to the original publication and authors. The full terms of this license may be seen at: http://creativecommons.org/licences/by/4.0/legalcode

Vol. 11, No. 1, 2021, Pg. 327 - 337 


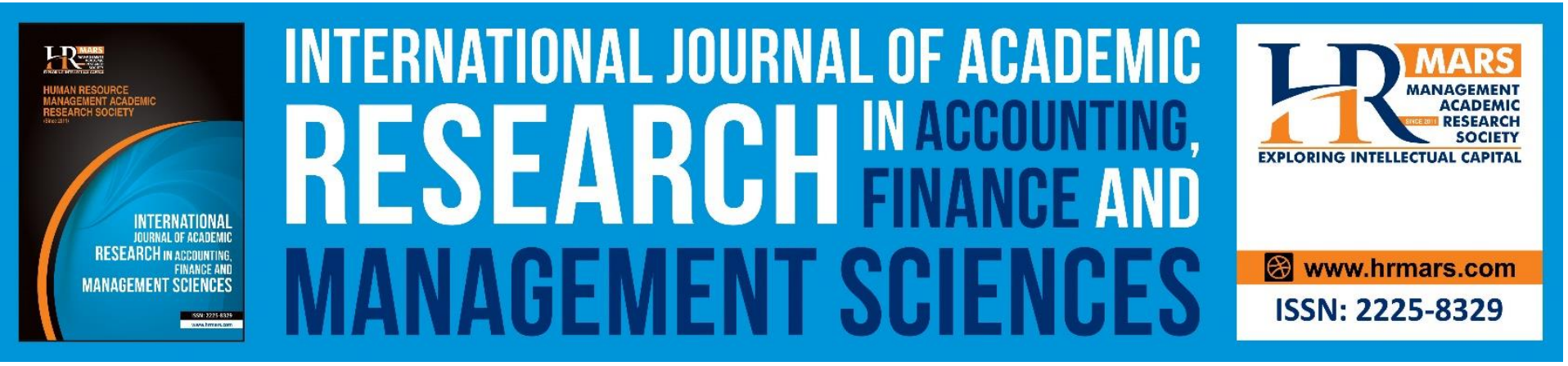

\title{
The Covid-19 Dashboard Sector Specific Impact: Malaysia Financial, Consumer Products and Health Care Services
}

\author{
Nur'Asyiqin Ramdhan ${ }^{1}$, Noorita Mohammad², Nur Liyana Mohamed \\ Yousop $^{3}$, Zuraidah Ahmad ${ }^{4}$, Zuraidah Sipon ${ }^{5}$ and Norhasniza Mohd \\ Hasan Abdullah ${ }^{6}$ \\ 1,2Faculty of Business and Management, Universiti Teknologi MARA, Puncak Alam Campus, 42300 \\ Selangor Malaysia, ${ }^{3,4,5,6}$ Faculty of Business and Management, Universiti Teknologi MARA, Segamat \\ Campus, 85000 Johor Malaysia. \\ Email: asyiqin@uitm.edu.my
}

\begin{abstract}
The Covid-19 outbreak triggered in 2019 and continues the spread around the world. In March 2020 Malaysia has started implement a series of Movement Control Order (MCO) until the series continues to Conditional Movement Control Order (CMCO) and Recovery Movement Control Order (RMCO). This paper aims to examine the sector specific impact namely financial, consumer products and healthcare services index during the prolong of MCO period. Finding shows, the number of Covid-19 daily cases shows a constant significant positive impact towards those sectors. In addition, the external independent also included with the resulted the China daily cases significantly impact the sectors with the mix directions. The healthcare services index tends to result the highly performed sector during the pandemic outbreak. Overall, the results suggest that these stocks are positively respond to the Covid-19 pandemic and this response differs over the period depending on the stage of the duration.
\end{abstract}

Keyword: Covid-19, Sectoral, Indices, Stock Market, Malaysia

\section{Introduction}

Covid-19 known as a new type of infectious disease that caused by a strain. This strain is a kind of virus that has a potential to cause respiratory problems in humans. The world early case was officially reported in December 2019, but it has emerged in the Wuhan region of China earlier than that. The pandemic is causing enormous effect on real economic activities; however, the degree of real effect is yet obscure. Starting March 2020, in excess of hundred nations around the globe had just organized the incomplete or full lockdowns and air and intercity travel was somewhere around 70 to 90 percent when contrasted with figures from March 2019 in significant world urban communities influencing 
billions of individuals (Dunford et al., 2020). Major social and supporting occasions have been suspended. Public level reactions to the infection are likewise uncommon.

On the one hand, governments are taking crisis measures, for example, closures for social removing and interests in testing and isolating the speculated cases and treating the affirmed cases, to contain the infection. Then again, governments, from money services to national banks, are turning out help and upgrade bundles to contain the monetary harm. As a world connected economy, the effects of the outbreak have caused the deaths and morbidity of the people (McKibbin and Fernando, 2020) and encouraged people to practice social distancing that led to the financial markets, corporate offices, business and events collapse (Ozili and Arun, 2020).

The first case of Covid-19 was detected on 24 January 2020 in Malaysia known as imported case until the localize clusters emerged and by 16 March it has spread in every state and federal territory. The cases increased intensely (refer to Figure 1) starting from 125 cases on March 2020 to 2,626 cases until end of March 2020. This outbreak has made the government of Malaysia to announce a Movement Control Order (MCO) starting from 18 March 2020 to 31 March 2020. The two weeks of MCO duration has been extended to the second phase of MCO due to the uptrend of the cases until 14 April 2020. At the same time, China lockdown do impact Malaysian economic cycle as it is affecting the supply and demand in the industry.

According to Malaysia Department of Statistic, Services industry is the primary driver of the economic growth in Malaysia. It contributes 56\% known as the largest contributor to the country GDP including financial and healthcare services industry. Sectoral indices synopses and benchmarking information of certain industries or sectors that allows investors keep tracking the specific stock sectors. Analysing the indices will provide investors to track the sectoral performance in securities market. According to the Bursa Malaysia statistical index data, each sectoral index has a different trend phase reaction on before and after throughout the series of MCOs. The Covid-19 outbreak is one of the most serious encounters by financial industry and consumer products services as it impacted on the lower incomes, banking business, production shutdowns and resulted to the slow phase of index recovering. Differently, Covid-19 has not hampered the health care industry as the performance reporting an uptrend since before the emergence of the outbreak.

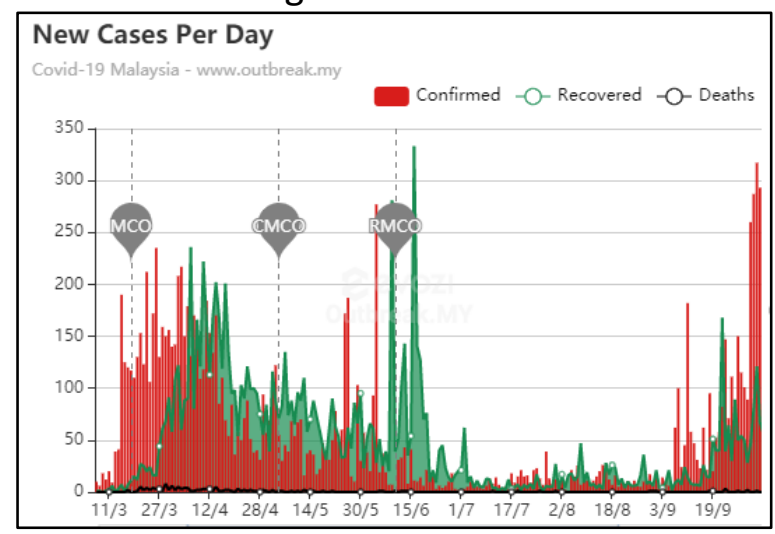

Source: Outbreak.my website

Figure 1: New daily cases and death during MCO, CMCO and RMCO

Although, other industry such tourism was heavily impacted due the outbreak as previously in 2019, the first three quarters data highlighted that more than ten million tourists from Singapore and China visited Malaysia (Azman, 2020). However, the industry is keep observing and improving accordingly 
to the series of MCO implementation. For example, during RMCO Malaysians are back to the demand of local accommodations as the they are no restriction to cross over state accordingly. This shows some industry would react directly to the MCO announcement and some are not. At present, the main gap in the existing research is the absence of inclusive sight on the impact of pandemic Covid19 towards the specific sector in the country. In addition, it is also worth remarking that how Covid19 correlated to the major sector in the country during the different phase of MCO. Thus, this study discourses the knowledge gap by taking Malaysia as a study sample to determine the Covid-19 outbreak impact towards the selected stock indices.

The highlight of this study will might be highly relevant to the investors, industries, and future researchers. As for investors or traders, this study helps investors to tackle or predict the movement of sector trends with the help of the event since the movement of stock market indices illustrates the overall market sentiments. On the other hand, this study is related on the impact on contribution of the sectors Malaysia economy during the pandemic event which will acknowledge and encourage the corporation to contribute more to the Malaysia's Gross Domestic Product (GDP) even in the hard time. This study contributes to the literature in two important ways; First, it underwrites to the empirical results of prolong duration during the outbreak where at this stage, effective vaccines is still not available. Second, this paper contributes to the sectoral emerging literature of Covid-19 concerning to the selected industries. This paper is organized and structured as follows: Section 2 analyses the empirical literature related to current Covid-19 and SARs outbreak. Section 3 discusses the data and methodology. Section 4 explain the interpretation of results and findings. Lastly, the conclusion and recommendations for future research.

\section{Literature Review}

In 2002, Severe Acute Respiratory Syndrome (SARS) disease had also knockout the economy widely with loss estimation from US $\$ 30$ to $\$ 100$ billion. Sectoral study including aircrafts, the travel industry, retail and biotech areas. Information of 32 firms was accumulated and the outcomes demonstrated that the SARS episode adversely affected aircrafts, travel industry and retail sectors. In any case, they found that the SARS outbreak would in general exaltation the performance of biotechnology organizations. Moreover, Wong (2008) analysed the response of the lodging business sector to the SARS episode and uncovered that the cost of domains began to decline by 1.6 percent when the SARS pandemic started, yet bequest costs in Hong Kong didn't show any eruption to the SARS flare-up. Nevertheless, the concern of several studies regarding on the natural disasters contributed to the literature are common. Goodell (2020) highlighted a review on natural disasters such as climate change, localized disasters, nuclear wars and Coronavirus pandemic is exacting extraordinary worldwide ruinous monetary instability.

Previous study on future effect of tourism and hospitality industry due to MCO shows this pandemic is negatively influence to the industry (Karim, Haque, Anis, and Ulfy, 2020). In contrast, Laing (2020) found that the mining sector in U.S have a severe potential consequence in short, medium and longterm for the industry. At the same point, financial services firms worldwide also were struggling to preserve stability in their operation during this crisis. This industry is an important factor in the economic development as it was among the content on the stimulus package of mitigating the immediate impact of Covid-19 such restructuring of loans and encouraging investment growth (Medina, 2020). 
INTERNATIONAL JOURNAL OF ACADEMIC RESEARCH IN ACCOUNTING, FINANCE AND MANAGEMENT SCIENCES

Vol. 11, No. 1, 2021, E-ISSN: $2225-8329$ @ 2021 HRMARS

The powerful impact on the pandemic towards financial stock market also has been highlighted by Baker, Bloom, Davis, Kost, Sammon and Viratyosin (2020) where the government restrictions in a services-oriented economy was the main factor of U.S stock market reacted unprecedented to Covid19 compared to the previous pandemic happened in 1918-19,1957-58 and 1968. Ozturk, Sisman, Uslu and Citak (2020) found that sectoral indices in turkey were significantly affected by the global Covid19 cases number and more specifically in sectors such metal products, machinery and sports, insurance and banking sector. Regardless the sizable on economic downturn, food and beverages, wholesale and retail trade and real estate investment sectors have been less affected on the pandemic.

Malaysia health care services currently operating a two-tier system mainly of both government bases with co-existing private health care system. An event study paper in selected Asian countries by Liu, Manzoor, Wang and Zhang (2020) indicate that the stock markets in major affected countries and area fell quickly after the Covid-19 outbreak. Asian countries experienced a negative abnormal return compared to the other countries in the stock indices causes by pessimistic and future fears and uncertainties. At the early period of the pandemic in Malaysia, none of the private health care practitioner equipped with the Covid-19 test tools.

An interviewed by CodeBlue with medical professionals predicted that the impact of Covid-19 on the private health care industry may continue for at least three months and maybe up to a year and beyond the end of MCO. They also highlighted that half of total private spending comes from health purposes in the country. The implementation of $\mathrm{MCO}$ and lockdown resulted in a drop in the number of patients to private hospitals by 70 to 80 percent. In fact, this situation may persist where patients are considering receiving treatment from private hospitals while medical tourism will also be affected by global lockdown (Durgahyeni, 2020).

By not only reviewing the impact on health and economic view, study by Shakeel, Naqvi and Hassali (2020) reviewed mapping consequences of the pandemic as the Malaysian authorities had realised the needs to ensure the availability of health resources and facilities in the country so that it will not worsen and spread to the other healthcare staff and patients. Covid-19 contamination cases in China by Zhou, Wu, Liu, Gao, and Gao (2020) analysed the monetary effects on a few ventures. They exposed that the quantity of cases decidedly related with execution of medical services industry and adversely related with different enterprises such tourism, constructions and transportation industry. In addition, Estrada, Park, and Lee (2020) inspected the effects of Covid-19 on four ventures, which included the airlines, utilities, tourism and trading in China. They found that all areas were unfavourably influenced by the Covid-19 episode, except for the utilities industries. They further clarified that the lockdown and medical area expanded electricity utilization and subsequently improved the industry performance.

Recently, Lee, Jais and Chan (2020) investigate a study of Covid-19 impact on Malaysia stock market. By using Kuala Lumpur Composite Index $(\mathrm{KLCl}), 13$ sectoral indices with the independent variables of Covid-19 cases, number of deaths, volatility index and Brent oil prices as external variable, daily from $31^{\text {st }}$ December 2019 to $18^{\text {th }}$ April 2020. The discoveries indicated that higher quantities of Covid-19 cases in Malaysia would in general unfavourably influence the performance of the market index and all sectorial lists, aside from the Real Estate Investment Fund (REIT) index. The outcomes likewise indicated that the Brent oil price and the index volatility would in general influence the Malaysian stock market performance. 
INTERNATIONAL JOURNAL OF ACADEMIC RESEARCH IN ACCOUNTING, FINANCE AND MANAGEMENT SCIENCES

Vol. 11, No. 1, 2021, E-ISSN: 2225-8329 @ 2021 HRMARS

In a nutshell, the empirical studies reviewed and explored a major scope of indices with the effect of Covid-19 of a country. Previous study in Malaysia has covered all sectoral indices in the early time of MCO which the daily data covered until the first month of MCO implementation. However, the influence of Covid-19 on sectoral view with the extended MCO are lacking in literature. Thus, this study attempts to examine the impact of Covid-19 towards the top three sectoral indices ranked by Bursa Malaysia as of November 2020. Meanwhile, it also fills this knowledge gap by exploring the impact by extending the observation with the selected specific sector throughout the series of MCO in Malaysian stock market.

\section{Data and Methodology}

This section will explain the sample, sources of data and analysis that used in this study. To examine the impact towards financial, consumer products and healthcare services index, this study used the daily data of ranging period from $16^{\text {th }}$ March 2020 to $25^{\text {th }}$ September 2020. This duration represents the different phase series of MCO. Varies sources were used to collect the data. For dependent variable, indices used for financial, consumer products and healthcare services were taken from the website of www.investing.com. The selection of the sectoral industry in this study was based on the top three major contributors to the total market capitalization ranked by Bursa Malaysia sectoral index series data as of $30^{\text {th }}$ November 2020 (refer to Table 1).

For independent variables, the data for number of confirmed cases and fatalities from Covid-19 was collected from John Hopkins University (JHU) Coronavirus Resources Centre for two countries were extracted. These data are available and downloaded on a day-to-day basis for Malaysia and China (total case daily). The justification of taking China as external variables in this study was due to (i) the Covid-19 is initiated form China and any hikes in everyday cases tend to affect the whole economy (ii) According to Malaysia Department of Statistics, China is the Malaysia top trading partner in foreign investments and tourism sector. Next, Brent Crude Oil Price also used in this study as independent, and the data extracted from investing.com website for the same daily covered period.

Several analyses were conducted to fill the study objectives. First, all collected data were analysed by the descriptive to see the summary statistics such as the most volatile index, minimum and maximum numbers of the variables. Next, correlation matrix analysis used to examine the correlation among the variables.

Table 1: Total percentage of Bursa Malaysia Sectoral Index Series by Market Capitalization

\begin{tabular}{|l|c|c|}
\hline Sectoral Indexes & $\begin{array}{c}\text { Market Capitalisation } \\
\text { (RM billion) }\end{array}$ & $\begin{array}{c}\text { Market Capitalisation } \\
\text { (percentage) }\end{array}$ \\
\hline Financial Services & 326.24 & $19.64 \%$ \\
\hline Consumer Products & 245.29 & $14.77 \%$ \\
\hline Healthcare & 210.18 & $12.65 \%$ \\
\hline Industrial Products and Services & 187.95 & $11.31 \%$ \\
\hline Plantation & 136.37 & $8.21 \%$ \\
\hline Telecommunication and Media & 135.31 & $8.15 \%$ \\
\hline Utilities & 120.51 & $7.26 \%$ \\
\hline Transportation \& Logistic & 67.92 & $4.10 \%$ \\
\hline Technology & 59.55 & $3.58 \%$ \\
\hline Property & 54.90 & $3.31 \%$ \\
\hline Energy & 45.04 & $2.71 \%$ \\
\hline
\end{tabular}


INTERNATIONAL JOURNAL OF ACADEMIC RESEARCH IN ACCOUNTING, FINANCE AND MANAGEMENT SCIENCES

Vol. 11, No. 1, 2021, E-ISSN: 2225-8329 @ 2021 HRMARS

\begin{tabular}{|l|c|c|}
\hline Real Estate Investment Trusts & 40.17 & $2.42 \%$ \\
\hline Construction & 31.27 & $1.88 \%$ \\
\hline Total & $\mathbf{1 6 6 1}$ & $\mathbf{1 0 0}$ \\
\hline
\end{tabular}

Source: Bursa Malaysia Official Website (As of 30 November 2020) Lastly, this study applied the Ordinary Least Square (OLS) regression analysis to determine the impacts of Covid-19 pandemic on the top three stock indices in Malaysia. The regression model to be tested in this study were:

$S I_{i, t}=\alpha+b_{1} M C_{M, t}+b_{2} M D_{M, t}+b_{3} C C_{C, t}+b_{4} C D_{C, t}+b_{5} B R E N T_{, t}$

(Equation 1)

Where $S I_{i, t}$ indicates the sectoral indices of financial, consumer products and healthcare services at day $t, M C_{M, t}$ is the number of confirmed Covid-19 cases in Malaysia at day $t, M D_{M, t}$ is the number of fatalities in Malaysia at day $t, C C_{C, t}$ interpret the number of confirmed cases in China at day $t, C D_{C, t}$ interpret the number of confirmed death in China at day $t$, and finally BRENT, $t$ represent the Brent Oil Price at day $t$. Furthermore, this paper also applied a two diagnostic test to check the OLS regression model. This includes the multicollinearity and auto-correlation test. To test the multicollinearity problem Variance of Inflation Factor (VIF) were used. The VIF greater than 10 explained a multicollinearity problem (Montgomery, Peck, \& Vining, 2012). The d-statistics that are lower than the $\mathrm{dL}$ indicates an autocorrelation, whereas the $\mathrm{d}$-statistics that are greater than $\mathrm{dU}$ indicates no autocorrelation (Durbin and Watson, 1971).

\section{Findings}

This section presents the results of the study empirical analysis. Table 2 highlighted the summary statistics on the variables. From the results of the descriptive analysis, the coefficient variation was calculated to determine the volatility for each of the variables. Among the indices, maximum index value is come from financial services followed by healthcare and consumer products whereas the minimum indices represented by Malaysia death case. In addition, the coefficient variations on variables shows that the highest volatility variation represent by the Malaysia death data (1.83) followed by China case (1.29), healthcare index (0.41), Malaysia case (0.33), Brent Crude Oil Price (0.29), China death (0.13), financial index (0.08) and consumer products index (0.05). This indicates that performance of the financial and consumer products sectoral indices was quite constant during the sample duration.

Table 2: Descriptive Statistics

\begin{tabular}{|l|c|c|c|c|c|c|}
\cline { 2 - 7 } \multicolumn{1}{c|}{} & Mean & Median & Maximum & Minimum & Std. Dev. & CV \\
\hline Fin & 12658.68 & 12672.84 & 15534.21 & 1273.85 & 1134.32 & 0.08 \\
\hline Hc & 2614.92 & 2380.67 & 4456.09 & 1142.40 & 1081.80 & 0.41 \\
\hline Cons & 554.33 & 566.04 & 585.96 & 466.27 & 26.67 & 0.05 \\
\hline Mc & 7409.63 & 8553.50 & 10687.00 & 566.00 & 2474.50 & 0.33 \\
\hline Md & 0.62 & 0.00 & 6.00 & 0.00 & 1.14 & 1.83 \\
\hline Cc & 1786774. & 83360.50 & 6213817. & 80881.00 & 2318668. & 1.29 \\
\hline Cd & 4335.43 & 4638.00 & 4669.000 & 3217.00 & 563.38 & 0.13 \\
\hline Brent & 35.05 & 40.39 & 46.01 & 13.06 & 10.04 & 0.29 \\
\hline
\end{tabular}

Notes: Dependent variables: Fin refers to financial services index, Hc refers to the healthcare service index, Cons refers to the consumer index. Independent variables: Mc refers to the total Malaysia case, 
INTERNATIONAL JOURNAL OF ACADEMIC RESEARCH IN ACCOUNTING, FINANCE AND MANAGEMENT SCIENCES

Vol. 11, No. 1, 2021, E-ISSN: 2225-8329 @ 2021 HRMARS

Md refers to the Malaysia confirmed death, Cc refers to the total China case, Cd refers to the China confirmed death and Brent refer to the Brent Crude Oil Price.

Table 3 reports the Pearson correlation matrix between the variables. There was mixed correlation derived from the matrix for the sectoral stocks index. The strongest correlation is extracted from the correlation of total Malaysia case towards the consumer and products services index with the coefficient of 0.947 . This followed by the same independents $(0.813)$ and total China case $(0.855)$ towards the healthcare sector. Meanwhile, the three weakest correlation was resulted from the financial services index on its independent variables from the Brent Oil Price $(0.288)$ followed by the total case in Malaysia (0.257) and total China death case (0.252) respectively.

Table 4 represents the analysis and results for the regression. The R-squared for all stocks indices shows that the dependent variable was explained by the independent by more than $90 \%$ except for financial services sector. This can be related with the weak correlation of the independents towards the correlation matrix analysis at the beginning. All sectors are having a significant positive relationship with the total Malaysia of Covid-19 cases. This indicates that the Malaysia numbers of daily cases in the series of MCO did not effect on a downturn trend of the indices. On the other hand, the total fatalities in Malaysia did not give any significant impact towards the sectoral indices. This is relevant due to that death are comes after the confirmed cases and it does not affect the daily stocks performance.

Table 3: Results of Correlation Matrix

\begin{tabular}{|c|c|c|c|c|c|c|c|c|}
\hline Prob & Fin & Cons & Hc & Mc & Md & Cc & Cd & Brent \\
\hline Fin & 1.000 & & & & & & & \\
\hline Cons & 0.365 & 1.000 & & & & & & \\
\hline Hc & 0.216 & 0.743 & 1.000 & & & & & \\
\hline Mc & $\mathbf{0 . 2 5 7}^{*}$ & $\mathbf{0 . 9 4 7}$ & $\mathbf{0 . 8 1 3 ^ { * }}$ & 1.000 & & & & \\
\hline Md & $-0.176^{*}$ & $-0.622^{*}$ & $-0.535^{*}$ & -0.628 & 1.000 & & & \\
\hline Cc & -0.035 & $0.459^{*}$ & $\mathbf{0 . 8 5 5 ^ { * }}$ & 0.614 & -0.324 & 1.000 & & \\
\hline Cd & $\mathbf{0 . 2 5 2 *}$ & $\mathbf{0 . 8 5 3 ^ { * }}$ & $0.662^{*}$ & 0.871 & -0.658 & 0.408 & 1.000 & \\
\hline Brent & $\mathbf{0 . 2 8 8 ^ { * }}$ & $0.775^{*}$ & $0.851^{*}$ & 0.809 & -0.630 & 0.573 & 0.786 & 1.000 \\
\hline
\end{tabular}

Notes: ${ }^{*} \boldsymbol{p}<0.01,{ }^{* *} \boldsymbol{p}<0.05$. Dependent variables: Fin refers to financial services index, Hc refers to the healthcare service index, Cons refers to the consumer index. Independent variables: Mc refers to the total Malaysia case, Md refers to the Malaysia confirmed death, Cc refers to the total China case, $C d$ refers to the China confirmed death and Brent refer to the Brent Crude Oil Price.

For the results of external variables China cases, it shows all sectors are significantly impacted with different direction. Total daily case in China is negatively significant with Malaysia financial and consumer indices but resulted a positive impact to the healthcare indices. This result align with nature of the sector as the pandemic increases globally, the demand for the healthcare services tends to be high in country. The same results gained for the total daily death case in China that shows a significant negative impact towards the healthcare sector. The Brent Crude Oil price shows a significant positive impact towards financial and healthcare services indices. For the diagnostic test on multicollinearity, all the independent variables show a centred VIF ranging from 1 to 6 which indicates that there is no 
INTERNATIONAL JOURNAL OF ACADEMIC RESEARCH IN ACCOUNTING, FINANCE AND MANAGEMENT SCIENCES

Vol. 11, No. 1, 2021, E-ISSN: 2225-8329 @ 2021 HRMARS

multicollinearity problem relies in the data. While the auto-correlation test ranging from the amount of 0 to 2 respectively.

In a summary, the number of Covid-19 daily cases shows a constant significant positive impact towards the Malaysia financial, consumer products and healthcare services. This indicates that the prolong series of MCO tended not give a negative correlation impact towards the stock indices. However, the results are different with the previous literature who tested the impact during the earlier of the outbreak. These results suggest even though vaccines for the Covid-19 yet to be explored, the stocks reacted normally and indices recovering with the uptrend chart. The government action on giving a series of Economic Stimulus package amounting RM20 billion (27 ${ }^{\text {th }}$ February 2020) and RM230 billion (27 $7^{\text {th }}$ March 2020) enhanced the Malaysia economic during the MCO periods. In addition, the number of case and fatalities in China gives a mixed impact towards the three sectoral indices. Finally, as one of the exporting oil country, Brent Crude Oil Price impacting only on the financial and healthcare services sectoral during the tested study period.

Table 4: Results of Regression and Multicollinearity Test.

\begin{tabular}{|c|c|c|c|c|c|c|c|c|}
\hline & C & Mc & Md & Cc & $C d$ & Brent & $\begin{array}{c}\text { R- } \\
\text { Square }\end{array}$ & $\begin{array}{l}\text { Durbin- } \\
\text { Watson }\end{array}$ \\
\hline \multirow[t]{2}{*}{ Fin } & 11832 & 0.1864 & 58.973 & -0.0002 & -0.4119 & 44.2160 & \multirow{2}{*}{0.1700} & \multirow{2}{*}{1.855814} \\
\hline & 0.0000 & $0.0460 * *$ & 0.5846 & $0.0003 *$ & 0.2726 & $0.0096 *$ & & \\
\hline \multirow[t]{2}{*}{ Cons } & 475.00 & 0.0112 & -0.299 & 0.0000 & -0.0013 & 0.1903 & \multirow{2}{*}{0.9245} & \multirow{2}{*}{0.656494} \\
\hline & 0.0000 & $0.0000 *$ & 0.6953 & $0.0000 *$ & 0.6345 & 0.1134 & & \\
\hline \multirow[t]{2}{*}{$\mathrm{Hc}$} & 563.47 & 0.0889 & -11.90 & 0.0002 & -0.1800 & 50.3949 & \multirow{2}{*}{0.9337} & \multirow{2}{*}{0.203138} \\
\hline & 0.0693 & $0.0005^{*}$ & 0.6821 & $0.0000 *$ & $0.0763 * *$ & $0.0000 *$ & & \\
\hline VIF & & 6.581 & 1.891 & 1.972 & 5.567 & 3.587 & & \\
\hline
\end{tabular}

Notes: ${ }^{*} \mathbf{p}<\mathbf{0 . 0 1}, * * \mathrm{p}<\mathbf{0 . 0 5}, * * *$. Dependent variables: Fin refers to financial services index, Hc refers to the healthcare service index, Cons refers to the consumer index. Independent variables: Mc refers to the total Malaysia case, Md refers to the Malaysia confirmed death, Cc refers to the total China case, Cd refers to the China confirmed death and Brent refer to the Brent Crude Oil Price.

\section{Conclusion}

This paper contributes to the emerging literature on the outbreak of pandemic Covid-19 with the contribution to sectoral specific impact namely financial, consumer products and healthcare services in Malaysia. The daily data on confirm cases and fatality together with the other external variables provide by China cases and death and Brent Crude Oil price were used from the early announcement of MCO until the RMCO period (16 $6^{\text {th }}$ March $-25^{\text {th }}$ September 2020). The results from the regression concluded that all selected sectors are having significant positive impact to the stock indices. This study also recommends that the prolong duration of MCO tended having a positive reaction towards the stock's indices. Interestingly, healthcare services sector shows the most positively and actively effected during the tested duration. For future research, this study suggests for financial sector, the variables proxies should be explored since the lowest $r$-squared reported in the analysis. In addition, future analysis also can be done by applying a different and longer sample duration during the pandemic hit in and outside the country. 
INTERNATIONAL JOURNAL OF ACADEMIC RESEARCH IN ACCOUNTING, FINANCE AND

MANAGEMENT SCIENCES

Vol. 11, No. 1, 2021, E-ISSN: $2225-8329$ @ 2021 HRMARS

\section{References}

Azman, N. H. (2020). COVID-19 could cost Malaysia's economy RM5.9b this year. The Malaysian Reverse. Retrieved from https://themalaysianreserve.com/2020/02/24/covid-19-could-costmalaysias-economy-rm5-9b-this-year/

Baker, S., Bloom, N., Davis, S., Kost, K., Sammon, M., \& Viratyosin, T. (2020). The Unprecedented Stock Market Impact of COVID-19. doi:10.3386/w26945

Durbin, J., \& Watson, G. S. (1971). Testing for serial correlation in least square regression III. Biometrika, 58(1), 1-19.

Durgahyeni, M. (2020). Pandemic Hits Malaysian Private Health Sector Hard. Retrieved July 10, 2020, from https://codeblue.galencentre.org/2020/04/20/pandemic-hits-malaysian-private-healthsector-hard/

Estrada, M. A. R., Park, D. H., \& Lee, M. S. (2020). The evaluation of the final impact of Wuhan COVID19 on trade, tourism, transport, and electricity consumption of China. Retrieved from https://ssrn.com/abstract=3551093

Goodell, J. W. (2020). COVID-19 and finance: agendas for future research. Financ. Res. Lett 101512. https://www.bbc.com/news/world-52103747

Karim, W., Haque, A., Anis, Z., \& Ulfy, M. (2020). The Movement Control Order (MCO) for COVID-19 Crisis and its Impact on Tourism and Hospitality Sector in Malaysia. International Tourism and Hospitality Journal, 3(2), 1-07. doi:10.37227/ithj-2020-02-09

Laing, T. (2020). The economic impact of the Coronavirus 2019 (Covid-2019): Implications for the mining industry. The Extractive Industries and Society, 7(2), 580-582. doi: 10.1016/j.exis.2020.04.003

Lee, K., Jais, M., \& Chan, C. W. (2020). Impact of Covid-19: Evidence from Malaysian stock market. International Journal of Business and Society. 21. 607-628.

Liu, H., Manzoor, A., Wang, C., Zhang, L., \& Manzoor, Z. (2020). The COVID-19 Outbreak and Affected Countries Stock Markets Response. International Journal of Environmental Research and Public Health, 17(8), 2800. doi:10.3390/ijerph17082800

Mckibbin, W. J., \& Fernando, R. (2020). The Global Macroeconomic Impacts of COVID-19: Seven Scenarios. SSRN Electronic Journal. doi:10.2139/ssrn.3547729

Medina, A. (2020). Malaysia Issues Stimulus Package to Combat COVID-19 Impact. Retrieved July 10, 2020, from https://www.aseanbriefing.com/news/malaysia-issues-stimulus-package-combatcovid-19-impact/

Montgomery, D. C., Peck, E. A., \& Vining, G. G. (2012). Introduction to Linear Regression Analysis. Canada: John Wiley \& Sons.

Ozili, P. K., \& Arun, T. (2020). Spillover of COVID-19: Impact on the Global Economy. SSRN Electronic Journal. doi:10.2139/ssrn.3562570

Ozturk. O, Sisman, M., Uslu. H., \& Citak, F. (2020, June 30). Effects of Covid-19 Outbreak on Turkish Stock Market: A Sectoral-Level Analysis. Retrieved July 12, 2020, from https://doi.org/10.17218/hititsosbil.728146

Shakeel, S., Hassali, M. A., \& Naqvi, A. A. (2020). Health and Economic Impact of COVID-19: Mapping the Consequences of a Pandemic in Malaysia. Malaysian Journal of Medical Sciences, 27(2), 159-164. doi:10.21315/mjms2020.27.2.16

Wong, G. (2008). Has SARS infected the property market? Evidence from Hong Kong. Journal of Urban Economcis, 63(1), 74-95. 
INTERNATIONAL JOURNAL OF ACADEMIC RESEARCH IN ACCOUNTING, FINANCE AND

MANAGEMENT SCIENCES

Vol. 11, No. 1, 2021, E-ISSN: 2225-8329 @ 2021 HRMARS

Zhou, L., Wu, K., Liu, H., Gao, Y., \& Gao, X. (2020). CIRD-F: Spread and influence of COVID-19 in China. Journal of Shanghai Jiao Tong University, 25(2), 147-156. 